KENTE, 2019,

Vol 1, No. 1, 15-28

\title{
The Failed Masculinist State in Africa: A Rejection of Phallic Man
}

Theresa Addai-Munumkum, PhD

Department of English

University of Cape Coast

Cape Coast

tennin@ucc.edu.gh

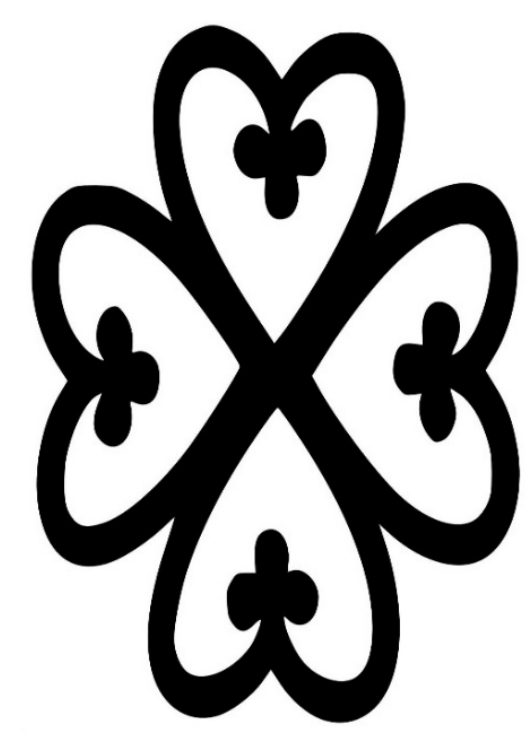

\begin{abstract}
African literature is famous for the depiction of a type of politics that tends to reflect the reality on the ground, spanning a panorama of incompetent leadership to gross political corruption. As a result, writing about politics in Africa tends to be a risky undertaking as many creative writers who criticize political leadership and corrupt practices in their works end up being jailed. Using contemporary African literature to discuss the postcolonial African Political State, this paper explores the nature of the state in West Africa in three novels, Chinua Achebe's A Man of the People, Anthills of the Savannah and Sembene Ousmane's Xala. Using the metaphor of an impotent masculinity, this paper argues that the political State in Africa is a failed one. From the dawn of independence to the era of democracy, the political state in Africa has had to grapple with failed leadership, corruption, injustice, the ever-widening gap between the rich and the poor etc., and it appears that these problems are becoming more.
\end{abstract}

\section{KEYWORDS}

Men, African politics, Phallic masculinity, Postcolonial State 
African literature is famous for the depiction of a type of politics that tends to reflect the reality on the ground. As a result, writing about politics in Africa tends to be a risky undertaking as many creative writers who critique politicians and policies in their works end up being jailed. Upon their release, many write about their experiences in what is popularly known as the "writer's prison journal." Much as we hail this genre, it ought to be said that this system of political repression should be seen as an indictment of the nature of the political state in Africa. It is therefore, pertinent to say that this phenomenon of African politics has given rise to a certain kind of literature.

Using contemporary African literature to discuss the postcolonial African political State, this paper explores the nature of the state in West Africa in three novels, Chinua Achebe's A Man of the People (1966), Sembene Ousmane's Xala (1974) and Achebe's Anthills of the Savannah (1987). Employing the metaphor of an impotent phallus this paper argues that the political State in Africa is a failed one. From the dawn of independence to the era of democracy, the political state in Africa has had to grapple with failed leadership, corruption, injustice, the ever-widening gap between the rich and the poor etc., and it appears that these problems are becoming more and more insurmountable. These texts have largely been read or studied with regard to the political state in Africa. This paper would apply a phallocentric reading to these texts and conclude that an obscene attachment to phallocentric definitions of masculinity in the texts has birthed political leaders who are impotent in the discharge of their duties. The titles of the texts as well as their protagonists indicate the centrality of the man in African politics, representing traditional metaphors of phallic masculinity. In psychoanalysis and other discourses on gender and masculinity, the focus has always been on the penis as the centre of a man's masculinity. This has resulted in phallocentricism and the phallic metaphor for masculinity. Flannigan-Saint-Aubin (1994) indicates that this phallic metaphor has both negative and positive articulations. Positively, to be phallic means to be penetrating: inquisitive, persistent, steady, courageous and objective. Negatively, to be phallic implies intrusiveness: violent, unyielding, discriminating, domineering and exploitive (Flannigan-Saint-Aubin: 248). Whether by design or default, the negative tendencies of phallic masculinity appear prominently in leaders who are autocratic and domineering. Even the positive qualities become magnified and distorted in such leaders, an example being Sam in Anthills. Qualities outside these are conceived as feminine and undesirable in the man. However, although very little study has been conducted by psychologists or psychoanalysts on the symbolic or metaphoric meaning that men attach to the testes and scrotum, Flannigan-Saint-Aubin asserts that there is enough evidence to warrant an appreciation of the testes and scrotum as part of the male genitalia and worthy of metaphoric analysis in masculine identity.

The positive characteristics deriving from the testicles which Flannigan-Saint-Aubin refers to as testicular are resourcefulness, steadfastness, patience and steadiness. A man is experiencing the testicular mode when he is nurturing, incubating, containing and protective. The negative potential of the testicle is referred to as testerical. The testerical masculine is characterized by testiness and all that being testy implies: petulant, fretful, insolent, temperamental and morose. It is also marked by a lack of direction and inertia. Most of these 
attributes are considered effeminate and undesirable in the man. Flannigan-Saint-Aubin concludes then that within patriarchy, there is a denial of the testicular/testerical masculine manifestations; and that these are projected onto woman, and not accepted as part of masculine behavior. However, he believes that men need to embrace these aspects of their masculinity by accepting the genitals the way they are because, "this is a first step toward moving beyond patriarchal imagination and in establishing a male posture and masculine discourse that transcend the phallic without denying its reality"(Flannigan-Saint-Aubin: 255

Before we explore this further we need to look at what is referred to as 'the state'. Scholars treat the state in two ways, either descriptively or substantively. Descriptively, scholars look at any leadership of a structure that governs anywhere, that is the ruling of a people in a particular territory. Substantively, a state is the structure of authority with particular features and this is differentiated from the society therefore hereditary kingships would not be part of the state. The state in this regard is very secular; its authority does not come from any divine or religious order. There is also a clear separation between the public and the private spheres. The wider the distance between the state and the society, the more "state" it is. There are laws that govern those in the state so that the interests of the people are protected. In this regard the state is seen as characterized by professionalism. The leaders in the state are not there based on anyone's whims; they are there because it has been realized that they are capable of doing their work. Writers like (Jallow 2007) and (Chabal 1999) agree that the state should be well established and institutionalized over time. It is however, pertinent to say at this point that the question of what the state is or should be is an on-going debate.

Many African states cannot be called 'states' in the truest sense of the word as they are poorly emancipated and very largely patrimonial (Chabal and Daloz, 1999). Other scholars also claim that the state in Africa has failed because it has not been able to fulfill the functions of the state. These functions, according to Edwin Madunagu (2009) are; 1. Coercive functions: - which involve the provision of security for all; 2. the ideological functions which constitute the institutions, religious doctrines and social movements that systematically disseminate their ideas and lastly, socio-economic functions which are those social and economic "conditions" of production that the members of the ruling classes and blocs provide. Madunagu indicates that the ruling elite needs to provide these social amenities and cannot afford to privatize goods and services such as: roads, electricity, schools, air transportations, industries etc. and expect to remain in power.

The African state that this paper is referencing refers to the period from the 1960's when many African countries attained independence from European colonialism. The structure of authority in the post-colonial period is indebted to the colonial period. Therefore, the modern African state is neither completely colonial nor pre-colonial. Rather its dominant components are from the colonial period. When political scientists say that the postcolonial state is not representative of the colonial, it is problematic because colonialism did not seek to create any kind of state that the west was practicing. Rather the colonizers were tyrannizing the colonies, exploiting them economically, gaining control of their territory and reforming their minds. There was no teaching of the natives about ruling themselves. The new crop of leaders who took over 
from the colonizers was aware of the defects of the colonial system and therefore much was expected of them to effect changes in leadership.

Sembene Ousmane's novel, Xala, details the fall of El Hadji Abdou Kader Beye from a wealthy member of the Chamber of Commerce to a poor man whose virility has deserted him. Set in post- independent Senegal, the novel opens with the celebration by the Chamber of Commerce and Industry on the appointment of the first African President. In the midst of the celebrations, El Hadji invites the members to witness his marriage of a third wife. On the night of the wedding, he is unable to have an erection to consummate the marriage. Desperate for a cure, El Hadji consults marabout after marabout until he becomes financially bankrupt, is disbarred from the Chamber, and loses his business and his second and third wives. In the end, he accepts the word of the mob of physically deformed beggars who promise to heal him as long as he allows them to spit on him.

The novel can be read as an allegory of the state with the president of the Chamber as the Head of State. In this regard, we will consider the timing as the period immediately after independence when the African took control of the affairs of government. The beggars are representative of the masses. In the 1970's the masses were referred to as the "scum" of the earth and Ousmane has literally used that to confront the elite. From the point of view of the elite, the beggars are lazy, dirty and beneath the regard of humanity. They serve as a metaphor of the common people. Rama finds herself in a position where she wants to help the common people but she is disgusted by them. Ideologically, she should be on their side so her disgust showcases the self-criticism that Ousmane wants the idealists to do; to show that supporting the masses is expensive. Secondly, the beggars' action in the end represents the confrontation - dreamed and envisioned - between the masses and the ruling elite; however, Ousmane refuses to show the success of the revolution, so the novel ends with a stand-off. Although the beggars represent the masses, the members of the Chamber are not the bourgeoisie because they do not produce anything. They are actually managers of other people's property and businesses. . El Hadji we are told, was just a front for overseas investors (3). The African bourgeoisie as presented in Xala are unproductive, impotent, and not virile. However, the modern state is a state of big business, the state of the industrial class, the bourgeoisie, and the inability of the African bourgeoisie to perform is part of the crisis of the state. Sam Raditlhalo (2005: 172) refers to this as the xala afflicting postcolonial countries in a capitalist world.

The pervasiveness of impotency is also reflected in the people's corrupted materialistic values and dependency upon European culture. Oumi, El Hadji's second wife is materialistic in that she has taken up the capitalist consumer culture in Dakar, and she does not hesitate to abandon El Hadji and carry away all the property when his fortune crumbles. Like Oumi, El Hadji and the members of the chamber are satirized for their capitalistic consumerism. Aaron Mushengyezi indicates that taking on a virgin his daughter's age becomes for El Hadji a celebration of his wealth. The money for the lavish wedding had come from 100 tons of rice meant for the hungry peasants that El Hadji had diverted. The wedding is thus a symbol of his insatiable greed for accumulation and self-aggrandizement.

The alienation of the ruling class from the masses is seen in the treatment of the beggars. El Hadji complains to the President of the Chamber that the beggars in front of his shop are a 
nuisance he cannot abide. And the president replies with orders to the police to clean the streets because it is bad for tourism. This is definitely not the solution to the problem of rural-urban migration and destitution in Dakar. The members of the Chamber are also alienated from the people in the sense that they have become white men in black skins. They wear European suits, speak French, and despise their indigenous language and culture. El Hadji denounces his African identity and only takes it up when it serves his purposes.

Ousmane sees the tragedy of African politics as resulting from a crisis of inept leadership, symbolized by the xala on El Hadji. The Africans who take over the Chamber of Commerce are not only, "parrots of their colonial masters' ideology, but incompetent, corrupt managers. Their revolutionary rhetoric of 'African socialism,' 'Negritude,' and 'Pan-Africanism - reminiscent of slogans promoted by men like Kwame Nkrumah, Leopold Senghor, and Julius Nyerere becomes an empty cliché as soon as they come to power" (Mushengyezi 2004: 52). Similarly, Bernth Lindfors (2010) indicates that El Hadji's flaccid private part represents the wholesale public emasculation of Africa's petite bourgeoisie. He employs a phallocentric exegesis in reading the texts and concludes that El Hadji's swinging fortunes resemble the many contrasting images in the text of the curse of modern Africa.

In $A$ Man of the People, Odili declares that:

A man who has just come in from the rain and dried his body and put on dry clothes is more reluctant to go out again than another who has been indoors all the time. The trouble with our new nation ... was that none of us had been indoors long enough to be able to say 'To hell with it'. We had all been in the rain together until yesterday. Then a handful of us - the smart and the lucky and hardly ever the best had scrambled for the one shelter our former rulers left, and had taken it over and barricaded themselves in. And from within they sought to persuade the rest through numerous loudspeakers, that ... any more dissent and argument outside the door of the shelter would subvert and bring down the whole house. (Achebe, 1966: 37)

Achebe's A Man of the People details the activities of a corrupt government and the struggles of the intelligentsia to wrest power away from them. The story showcases the conflict between Odili Samalu, a graduate from the university and his former teacher, Chief, the Honourable M.N. Nanga, M.P. The conflict arises when the Chief sleeps with Odili's girlfriend who comes to visit the former when he accepts a stay at the Chief's house. In his bid for revenge, Odili teams up with other university graduates to form the Common People's Party as an intervention to the corrupt governance provided by the ruling government. This new elite is young and full of idealism and the desire to create a better country than that in which they live. However, it becomes quite clear that the new politics that the intelligentsia proposes is nothing different from the dishonest and corrupt tendencies of the old one.

Odili's motivation to join the party is dubious as his attitude towards the common people is that of contempt, "silly, ignorant villagers." Secondly, the integrity of the new party, The 
Common People's Convention, is compromised from the onset because a junior minister in the old party is behind their formation, then in the heat of the campaign; Max accepts money from Chief Koko in the ruling party to step down from the elections. Osei-Nyame Jnr (2001) sees Odili's and Max's political endeavors to proceed differently from the old dispensation of Chief Nanga and Koko as merely illusionary and not possible as a result of the similar ideas these two have of the state machinery. This is evidenced at the launch of the party, CPC, when Max tells the people that it is time for them to also begin to enjoy the benefits of the state by voting their own into office.

Morrison (2006: 129) also sees the similarities between Nanga and Odili, and invariably between the old and the new dispensation by saying that Odili, "is... an equally poor progenitor of change". Max's idealism could be said to have germinated from a desire to rid the nation of the corrupt, self-serving politicians, however, when he accepts money from Chief Koko, he undermines the veracity of his intentions. This juxtaposition of Odili and Chief Nanga is seen by Morrison as a deliberate attempt by Achebe to show "them as mutually inadequate, equally compromised by greed, egotism and ambition" (Morrison, 2006: 130).

In the end, however, none of the parties gets the chance to enjoy power because in the wake of the violence following the elections, the military stages a coup and takes control of the nation. Many, like Odili welcome the coup as a solution to the political problems in the country. However, once again, Odili is not interested in the effect of the coup on the people or the state, he is happy that Nanga is no more a threat to his intentions of marrying Edna, for after Nanga is arrested; Edna's father gives in quickly for the marriage proceedings to begin. This euphoria or relief over the coup is considered problematic by many. Odili believes that nothing has changed. The people have now rejected the deposed leaders; the same leaders they were hailing a few pages back. Chief Koko is now a thief and Max has become a hero overnight. The novel ends without presenting a redemptive solution to the problem of the failed state.

The metaphor of the rain as it appears in the passage on page 34 is important for this discussion. The state is seen as a shelter from the rain; the rain being the situation of poverty and powerlessness. According to the passage, just as a shelter provides warmth and protection from the rain, so is the state seen as the solution to poverty and obscurity. As a result, because the people have been too long in the rain; since they have been without for a long while, the ablest ones who have entered the shelter are not willing to come to terms with leaving it and going back outside. Odili sums this up further by saying, "We ignore man's basic nature if we say, as some critics do, that because a man like Nanga has risen overnight from poverty and insignificance to his present opulence he could be persuaded without much trouble to give it up again and return without much trouble to his original state" (Achebe, 1966: 34).

It is a sad commentary on the nation where the state is seen as a refuge for a few, as a shelter from poverty with no regard for the people. The politician's role is depicted as that of a divided one. He must serve both the constituency which has elected him and the Government of the country as a whole, and in the African state shown in the world of the novel which is a conglomeration of local loyalties; this is almost impossible (Carroll 1980). How then does Nanga become a man of the people? The people do not remain ignorant of the situation at hand, they show a firm grasp of the politics of state building when the ex-policeman at the launch of CPC tells Max, "We know they are eating," he said, "but we are eating too" (Achebe 1996: 117). And they therefore encourage Odili, as one of their own, to also go and bring them their share of the 
national cake. This mentality leads to the birth of the patrimonial system, which in effect leads to the "revenge" of civil society as pertains in Xala.

The shelter thus becomes an exclusive "imagined community" that fails to incorporate many who would become citizens of the state. This leads to the crisis of political community (Chabal and Daloz 1999). The crisis of the "imagined community" becomes palpable when viewed in the light of what western educated Africans did. They quickly built an imagined community out of a set of ideas inherited from their colonial masters. They themselves were certainly not going to be left in the rain, but they failed to incorporate many who would become citizens of the new state. Any groups that opposed the narrow, sometimes, ethnic, nationalistic agenda of these elites were marginalized. Sometimes coercion was employed when necessary.

Dubem Okafor (2001) attributes the cynicism and apathy among the masses to the disillusionment of independence in the independent state. However, in the text, we find that the people have had no illusions about independence and the state politics:

The people themselves, as we have seen, had become even more cynical than their leaders and were apathetic into the bargain. 'Let them eat,' was the people's opinion, 'after all when the white men used to do all the eating did we commit suicide? Of course not. And where is the white man today? He came, he ate and he went. But we are still around ... it may be your turn to eat tomorrow. Your son may bring home your share' (Achebe 1966: 144)

Still looking at the quotation we realize that the people in power are not necessarily the most qualified to lead the nation, they are not the ones with the country's best interests at heart; they are simply the ones who have been lucky enough to find themselves there, and are determined to stay out of the rain and keep dry. Secondly, they have also barricaded themselves in there. This presupposes that there is no admitting of new members to share the shelter and they are also not ready to leave those thresholds of power. This is seen in the varied and violent attempts they make to win the elections. Odili himself knows that his party will not win the elections; their best bet might be to dent the ruling party's armor of security. Inherent in the metaphor is the idea that those in the shelter want those without to keep quiet and not complain because any form of complaints and dissent will bring down the house. This is clearly a matter of beating a child and forbidding him to cry. As a result, they go about saying all kinds of ridiculous things about how difficult and challenging it is to be a politician; Nanga claims he is the "servant of the people," and advises anyone to run away from being a politician.

Herein lies the lack of accountability on the part of the ruling elite. To be accountable, the ruler must give citizens enough opportunity to come into the "shelter". To be in the "rain" is to go unrepresented, or question the legitimacy of the "shelter". During the creation of nation-states in Africa, nationalist elites used the promise of representation, and access to the "shelter" of power, to gain legitimacy. After independence, nationalists quickly shut the doors. Chabal and Daloz write that "The politicians ... no longer needed to justify the legitimacy of their power. Their tenure of power, the proof of their nationalist success, was their badge of legitimacy" (1999:67). 
The relationship to power becomes a vicious cycle. Rather than bringing people into the "shelter" - even if only minimally, and even if only to create the appearance of representation the politicians shut the door and claimed that power equaled legitimacy. Left in the rain were all those who did not agree, which in this case was everyone except the politicians.

The shift in narration from first to the second person pronoun in the final sentence, perhaps show that Odili's disapproval of the politicians is now tempered by a closer insight into the temptations and problems of power (Carroll 1980). This description of the state shows a different mindset of what the state machinery is all about; perhaps, it is this way because of the huge expectations of the people yet, there is no discounting the selfishness of the politicians.

The theory of Alienation finds ample space in this discussion. The text appears to be saying that the moral turpitude is not due to the political leaders alone. The people do not comprehend the stature of the state apparatus. In this new structure, the system is alien to them. It speaks a different language than they know; however, as shall be discussed shortly, the people find a way to make meaning out of this alien structure. They domesticate it, leading to a completely different system than was intended. As for the elite, their western education in no way prepared them for the governance of the state.

The poverty theory or the Crisis of the Post-colonial State is another issue the novel highlights. Pre-colonial African societies were not commercialized or monetized. However, the advent of colonialism introduced the secularization of wealth. One did not have to be a king, merchant or farmer to control this wealth; one needed only a little education. Land was no longer an important marker of wealth, money was. Thus the gap between the rich and the poor became wider and wider. Added to this is the mono-crop theory of the crisis of the post-colonial state. The total dependence on one crop whose price is determined by the international market contributes to the crisis in the state. The government has not got the means to placate the people or the money to provide infrastructure to make life better. Thus its inability to manage inequality leads to much unrest and discontent in the state.

An unrest that sparks the conflict in Achebe's Anthills of the Savannah. The novel describes the political situation in an imaginary West African state, Kangan, where the military government has been in power for two years after the overthrow of the civilian government. The prevalent political situation is described through the experiences of three friends: Sam, a Sandhurst-trained officer who is the President of Kangan; Christopher Oriko, the Commissioner for Information; and Ikem Osodi, the editor of the National Gazette newspaper. Beatrice Okoh, the girlfriend of Chris and an official in the Ministry of Finance and Elewa, Ikem's semiliterate girlfriend also add their voice to the narration.

General Sam, the military dictator of Kangan, symbolizes the vicious elitism of the postcolonial nation-state. His rule is not legitimated by a democratic process. Rather he is the latest beneficiary of a series of military coups, whose main goal is not to ameliorate the deplorable condition of most of the people in the nation, but to profit from the power that control of the state affords. In the novel, Achebe satirizes the grotesque but tragic fear of the post-colonial leader as he gropes for the significance of popular protests (Erritouni 2006: 55). Chris says he does not understand why the military armed as it were with such armoury should be afraid of the masses that is unarmed, but that is precisely what Sam is afraid of. They fill him with fear and loathing. When the delegation from Abazon comes to present their petition to him, he 
dismisses their grievances as "sheer signs of indiscipline" (Achebe1987: 15). To defuse the perceived threat, he devises means that do not address the needs of the people.

Military school trained Sam to remain detached from political matters, and so even though he attended the prestigious Royal Military Academy, Sam was very much conscious of the fact that he was unprepared for his new political leadership role and it is therefore not surprising that he forms a kitchen cabinet to feel secure and protected. As a military president with an inclination towards democratic rule, he seeks life presidency through a referendum upon the advice from his colleagues, but when his plans fail, Sam becomes paranoid and this serves as the impetus for unfolding events in the novel, eventually leading to the tragic end of these three friends.

The absolute power with which he has invested himself has undermined the plurality of civil society and rendered the state coterminous with his will, making it, as a result, impossible for the Abazonians to redress their grievances except by recourse to his benevolence and generosity. Ironically, he accepts the homage paid him but denies the people their rights.

The elitist regime that governs Kangan has severed all ties to the people and to their needs. The elite cabinet ministers owe their allegiance to Sam and not the people, colluding with him to oppress the people. An example is Okong whose main concern is to curry favour with General Sam. Betrayal becomes important here where the very nationalists who immobilized the masses against colonialism, ignore the people and use the nation-state as a conduit to their selfish interests. Clement Okafor (2010) sees the novel as a failure of egotistical masculinity. In the novel, power and authority characterize masculinity in postcolonial Africa. Comparing Anthills to Things Fall Apart, he claims that a military dictatorship has supplanted the open discussion and collective governance that characterized masculinity in the precolonial system (154)

Some of the enlightened intellectuals refuse to be sycophants of General Sam. Ikem is one such intellectual. When Sam is made the Head of State of Kangan and Chris is appointed the Commissioner for Information, Ikem takes over the previous position of Chris as the editor for the National Gazette, the state owned newspaper; a position that frequently puts him in conflict with Sam. He is the most outspoken and reform-minded of the three. He received his education in London and after that he was:

Knocking about London doing odd jobs for publishers, reading his poetry at the Africa Centre and such places and writing for Third World journals, before his friends at home finally persuaded him to return and join them in nation-building. (Achebe 1987: 90-91)

Ikem uses words as tools to fight against the policies of the military government. His editorials are often harsh criticisms of the new ruling military government, and as a result of this Sam regards him as treacherous. To him, the role of the writer is to ask questions and make challenges; in the concluding part of his speech to the students, he exclaims that "writers don't give prescriptions. They give headaches!"(Achebe 1987: 161). Unlike Chris, Ikem is an extremist who is not keen on a step by step approach toward progress and so exploits his position as a journalist to call for a change. 
Closely related to Ikem is Christopher Oriko. Upon his acceptance of the position of the Commissioner for Information, Chris reports to Sam and finds himself in an uncomfortable situation of trying to get Ikem to comply with Sam's will. This position is no different from his role at Lord Lugard College where he then again served as the conciliator between the two. Achebe describes him as the middle of Ikem's intellectualism and Sam's socialite attitude: "I have always been in the middle. Neither as bright as Ikem and not such a social success as Sam" (Achebe 1987: 66). Saddled with the responsibility of defending the policies of a friend and military dictator, he strides between sycophancy, fidelity and subversion. He realizes the growing decadence in the government, but he is too much of a detached intellectual to commit himself to helping to end the growing degeneration in his friend and the cabinet.

All through the novel Chris' character goes through a progressive process of evolution. Even though implicit, Chris is described throughout the novel as a man of good repute, considerate and reserved. In the initial chapters of the novel however, he is in a powerless and lethargic state. Barely two or three years after accepting the appointment, his president and friend becomes a complete dictator, but Chris is ensnared and cannot help himself because of his commitment to his friend and the government. He is very much aware of the fact that the choices the president makes are wrong. He is displeased with the sycophancy of the other cabinet ministers but he is helpless to salvage the situation. His continual presence in such quarters changes Chris into becoming sardonic and comical, and his contempt for the presidency and the sycophant cabinet members becomes conspicuous:

On a bad day, such as this one had suddenly become after many propitious auguries, there is nothing for it but to lie close to your hole, ready to scramble in. And particularly to keep your mouth shut, for nothing is safe, not even the flattery we have become such experts in disguising as debate. (Achebe 1987:2)

Chris's nonchalant attitude here is to a large extent warranted due to the fact that hitherto as the editor for the national newspaper, he was in the position of an observer and probably a critic. He has now however been deracinated from his observer-critic position and plunged into an actual position of power, and has become part of an ineffective government of corrupt leaders. Chris is in a position of power yet, he is unable to end the exploitation of his people and change the society for the better. This feeling of powerlessness, despair, alienation and frustration is met with indifference on his part towards politics as well as a nonconformist attitude of subtle opposition towards the President and the members of cabinet.

As the story advances, Chris undergoes another metamorphosis. Sam demanding of him to fire Ikem and subsequently Ikem's death bring a form of enlightenment; the fact that unbridled power can be destructive, even in the face of friendship. During his escape to the Abazon Province Chris gains a new perception of the political and social life in Kangan; the leaders who are supposed to guide the nation into development are the most vulnerable to the glamour of power and prestige. All through his stay with friends, when he is trying to hide from Sam, and during his journey to Abazon, he experiences life as a common person and so regains a connection with his people and his country, an essential attribute that recent leaders do not possess. 
Towards the end of the book, when he is dying, Chris goes through a final change where his political worldview is redirected. He comes to the realization that every man is limited in one way or the other, and that a man who refuses to accept this limitation is a failure. In referring to himself as "The last green" (230) bottle, he alludes to the fact that life and power are like little green bottles, standing on a wall, that can fall without warning.

Chris is the midpoint between Ikem's radical approach towards the policies of Sam, and the conformism in the sycophant and corrupt cabinet officials. He is also a representation of the influence of colonialism on Africa and the African, especially the African intellectual, and the fissure between the new generation of Africans and their roots. Chris received British education, just like African intellectuals who decide to study abroad. However, unlike most Africa intellectuals who seem to throw away their rich African culture and ignore the ordinary African when they come into contact with European education, Chris gets in touch with the masses and consequently begins to understand his country better. By this Achebe is crusading for a paradigm shift in the ideological positioning of the educated African, and urges him to get down to his roots to help move his nation forward, since that is the essence of his education.

Unlike Ikem and Sam who die as a result of personal vendetta and direct consequence of inappropriate choices respectively, Chris dies so that the helpless and oppressed society represented by Adamma may live. Achebe seems to employ this messianic death of Chris to represent hope for a better Africa; the hope that even though the continent is filled with violence and corruption, there are leaders like Chris who would one day take on the defense of the marginalized. Whereas Achebe rejects the intellectual in A Man, in Anthills he appears to be advocating for the intellectual to take an active role in nation-building. Okafor says of the death of these three that they were consumed by a revolution that they initiated, leaving Beatrice to rebuild the decimated state they left behind.

The importance of Flannigan-Saint-Aubin's theory for this discussion lies in the conception of a restrictive understanding of masculine identity in the texts. El Hadji in Xala is locked in the limiting interpretation of his manhood as lord and provider for his family. Coupled with his excessive love of western culture, he maintains a lifestyle that he cannot afford on the money he makes from his business. Thus he needs to appropriate monies from elsewhere and cheat others to take care of his extravagant lifestyle and look after three large families. His desire to be "captain" leads him to marry a third wife. Ousmane says that, the "third marriage raised him to the rank of the traditional notability; it represented a kind of promotion" (Sembene Ousmane1976: 4), consequently, his downfall can be attributed to this desire to be a man of essence in the community. His strong attachment to traditional concepts of manhood, despite his repeated claims of being a modern man, blinds him to the realization that there could be other ways of being a man. His failure affects not just his immediate family but the state as a whole loses from his wrong choices. The danger in cultivating a phallic personality is embedded in the image of his flagging penis that is unable to perform; initially he was wealthy and powerful with an erect and performing penis, however, in the end, he becomes destitute and impotent.

Similarly, Chief Nanga in A Man used his position as MP to enrich himself at the expense of the people of his constituency. His luxurious suite is in sharp contrast to the poverty of his constituency, and yet, he still fights for more wealth, shamelessly using the people to enrich 
himself. His understanding of the local political slogan "I chop, you chop, palaver finish" has no room for a different way of doing things or viewing the world. Stuck as he is in the phallic structure of manhood, he uses people to achieve his aims, regardless of how much pain he is inflicting. Mention can be made of Sam and other characters in the texts but suffice it to say that many of these male characters reflect the same image of the phallocentric man determined to uphold a certain stereotypical image of manhood.

Another example of phallic representations of masculinity can be seen in the titles of the texts. In Xala, the attention is on the protagonist's sexual failure - impotence. In Anthills of the Savannah, the imagery of giant upright anthills on the savannah evokes a metaphoric picture of the erect penis. A Man of the People is full of sexual conquests that indicate a man's sexual prowess and ability. All these contribute to the stereotypical imagining of man as a sexual predator fixated on the one-dimensional definition of his identity.

Another interesting motif to the emphasis on phallic masculinity is the absence of women in leadership and significant roles. Not only are women related to the positions of spouses and significant others, they are also, especially in A Man and Xala, seen as the ones who bring about the downfall of the men. In Xala, the marriage of the third wife causes El Hadji's impotence, whilst the conflict between Odili and Nanga arises because the former's girlfriend is snatched by the latter. In Anthills, there appears to be a change where the women assume leadership roles but Beatrice only becomes significant in the absence of Chris and Ikem.

Are these writers indicating then that African leadership should be better handled by women in the presence of the failure of the men? El Hadji's daughter, Rama can be seen as a symbol of the kind of leadership that Ousmane wants to see in the leadership of men. She stands as the antithesis of all that the men are guilty of. She is a revolutionary woman; she had participated actively in the fight for freedom, she challenges patriarchy, denounces polygamy, and openly tells her father, "a polygamous man is never frank" (Sembene Ousmane 1976: 12). She is a defender of African culture: wears her hair short and plaited, wears African cloth, speaks to her father in wolof and refuses to drink imported Evian water. Hers is not the confused hybrid identity of her father.

Mushengyezi (2004:60) claims that Sembene Ousmane romanticizes Mother Africa and her revolutionary women because of his strong pan-African vision of a totally free, united, culturally dignified continent, where men and women have equal opportunities and aspirations. I ask the same questions he asks; has Ousmane lost hope in the emasculated African men who have failed in their leadership roles since independence? Does he see women as the hope for the salvation of mother Africa, as the ones who can take her to the "Promised Land"?

Among the intellectuals in Anthills, Achebe places a woman, Beatrice Okoh in a position of leadership, something that Ali Erritouni (2006:51) indicates that nationalism has disregarded but which post-colonial intellectuals have started to take seriously. In a 1987 interview with Anne Rutherford, Achebe informs us that he has elevated the main female character, Beatrice, to the level of an enlightened leader:

We have created all kinds of myths to support the suppression of woman ... I am saying that woman herself will be in the forefront in designing what her new role 
is going to be, with the humble cooperation of men. The position of Beatrice as sensitive leader ... is indicative of what I see as necessary in the transition to the kind of society which I think we should be aiming to create (1987: 4)

However, it is realized that the central position that Achebe assigns to Beatrice is not borne out by the actions in the novel. Erritouni sees Beatrice as serving other roles apart from being part of the enlightened intellectuals. She is "captain," "prophetess," and "priestess." As a woman leader she stands for a new awareness among Africans that women must be at last allowed to play significant roles in the affairs of their countries. One of her main functions in the novel is to inflect the predominantly male narrative of the nation-state with a feminist perspective. Erritouni argues that Beatrice becomes a de facto leader only after Ikem and Chris die, precisely the secondly role she has derided in Sembene Ousmane. Moreover, although her characterization as "priestess" and her identification with Idemili confer on her the status of leader, they equally cast her in the traditional role of motherhood. The contradiction in her representation lies in the fact that on the one hand, she occupies an emergent sphere that allows her to resist male chauvinism and to speak back to power; on the other hand, she is cast in traditional roles that domesticate her innovative function.

The contradictions in Beatrice's portrayal are also found in the portrayal of Rama. In spite of her perceived identification with the people, Rama is still locked in this capitalist ideology that the poor are poor because they are lazy, and thus she finds the beggars repugnant. These contradictions indicate perhaps reluctance on the part of these writers to categorically indicate that women will be better leaders than men. But the portrayals of both women and men show that there are certain attributes in both genders that are necessary for optimal leadership of the African State if only these characters will be open to embrace new conceptions of identity. This is in line with Okafor's argument that after egotistical masculinity has exhausted itself, complementary and redemptive potentials of womanhood comes. Thus Flannigan-Saint-Aubin's theory becomes pertinent for this discussion because the realization and acceptance of other ways of being a man other than the traditional phallocentric definitions will render them effective leaders who will be up to the challenge of managing the post-independent African state that is fraught with many tensions.

The rejection of phallic man, and the concomitant rejection of the overemphasis on the penis as the symbol of masculinity is realized in the failure of these men leaders, and the opening of the door to women as leaders further buttresses the fact that a new conception of masculinity is needed in state building. Gone are the days of the dictators and selfish corrupt bureaucrats interested in themselves. The time has come for the birth of the new leaders who are not hampered by traditional definitions of their gender. 


\section{References}

Achebe, C., 1966. A Man of the People. England: Heinemann.

---, 1987. Anthills of the Savannah. Nigeria: Heinemann.

Carroll, D., 1980. Chinua Achebe. London: MacMillan.

Chabal Patrick and Daloz J-P., 1999. Africa Works: Disorder as political instrument.

Bloomington: IUP.

Dubem, Okafor, D., 2001. Over-Determined Contradictions: History and Ideology in Achebe's A Man of the People. In: D. Okafor, ed. Meditations on African Literature. Westport, CT:

Greenwood, 89-100.

Erritouni, A., 2006. Contradictions and Alternatives in Chinua Achebe's Anthills of the Savannah. Journal of Modern Literature 29 (2): 50-74.

Flannigan-Saint-Aubin, A., 1994. The Male Body and Literary Metaphors for Masculinity. In: H. Brod and M. Kaufman, eds. Theorizing Masculinities. Thousand Oaks, California: Sage, 239-58.

Jallow, Matthew K, 2007. The African Bureaucracy and the Barriers to Democracy. The Gambian Echo 7 January.

Lindfors, Bernth, 2010. Penetrating Xala. In Helen N. Mugambi and Tuzyline Jita Allen, ed. Masculinities in African Literary and Cultural Texts. UK: Ayebia Clarke Pub. Ltd., 130- 134. Madunagu, E., 2009. Exploring the Failed State. Ngrguardiannews.com September, 2009.

Morrison, J., 2006. Chinua Achebe's A Man of the People: The Novel and the Public Sphere. In:

J. Morrison, ed. Scandalous Fictions: The Twentieth-Century Novel in the Public Sphere.

Basingstoke, England: Palgrave Macmillan, 117-135.

Mushebgyezi, A., 2004. Reimaging Gender and African Tradition? Ousmane Sembene's Xala Revisited. Africa Today, 5(1), 47-62.

Okafor, A Clement, 2010.Masculinity in Achebe's Anthills of the Savannah. In Helen N. Mugambi and Tuzyline Jita Allen, ed. Masculinities in African Literary and Cultural Texts. UK: Ayebia Clarke Pub. Ltd., 149-159.

Osei, Nyame K., 2001. Gender, Nationalism and the Fictions of Identity in Chinua Achebe's A Man of the People. Commonwealth Novel in English, 9-10, 242-262.

Ousmane, S., 1976. Xala. USA: Lawrence Hill Books.

Raditlhalo, S., 2005. Beggars' Description: Xala, the Prophetic Voice and the Post-Independent African State. English in Africa, 32(2), 169-184.

Rutherford, A., 1987. Interview with Chinua Achebe. Kunapipi 9 (2), 1-7. 


\section{Notes on Author}

Theresa Addai-Munumkum is a Senior Lecturer of African Literature at the Department of English, College of Humanities and Legal Studies at the University of Cape Coast, Ghana. She has published in Journals such as the West Africa Review, Spectrum: A Journal on Black Men, and the African Studies Quarterly and her research interests include Men and Masculinities, and Women in African Fiction. 